WATEG HYALIALES GRCWN CN OCMESTIL JEAGE

(NASA) 7 F

U1101as

$00 / 45 \quad 03484$

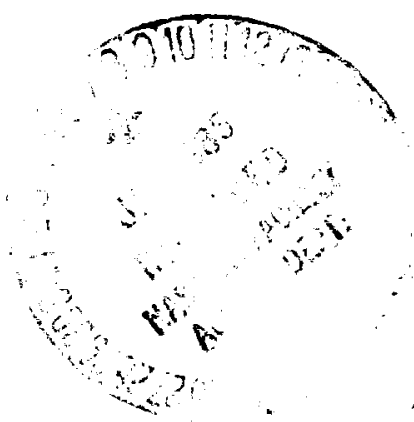

\title{
NUTRITIONAL COMPOSITION OF WATER HYACINTHS GROWN ON DOMESTIC SEWAGE
}

\author{
B. C. WOLVERION AND RI:BHC(AA C. MCDONALD'
}

\begin{abstract}
A nutrient analysis of water hyacinths grown in sewage waslewaters was conducted. Crude protein averaged $32.9 \%$ dry weight in the leaves, where it was most concentrated. The amino acid content of water hyacinth leaves was found to compare favorably with that of soybean and coltonseed meal. The vilamin and mineral content of dried water hyacinths met or exceeded the FAO recommended daily allowance, in many cases. Il is concluded that in favorable climatic cones. waler hyacinths grown in enriched mediums, such as sewage lagoons, could potentially serve as a substantial dietary supplement or nutrient source.
\end{abstract}

The water hyazinth. Iid thornia crassipes (Mart.) Solms, has perhaps been the subject of more intensive study than any other aquatic plant in recent years. A native of South America, this floating aquatic species has adapted exceedingly well to almost every area into which it has been introduced. In the southern United States, it is the number-one aquatic plant pest species. Due to its vegetative reproduction and extremely high growth rate, water hyacinths spread rapidly, clogging drainage ditches, shading out other aquatic vegetation and interfering with shipping and recreation (Holm et al., 1969; Raynes, 1972). Much effort and many dollar's have been devoted to the control of this prolific weed (Bates \& Hentges, 1976).

In the last several years, many investigators have directed their research endeavors to the utilization of the water hyacinth. Several scientists (Cornwell et al., 1977; Miner et al., 1971; Rogers \& Davis, 1972; Sheffield, 1967; Wolverton \& McDonald, 1976c) have considered the water hyacinth as a potential biological agent for treating sewage wastewaters and feedlot operations. The water hyacinth is particularly well-suited for this purpose, because it is extremely productive (Westlake, 1963; Wolverton \& McDonald, 1976c) and feeds directly from the water via its extensive root system. Wolverton and McDonald (1976c) reported growth rates as high as $\mathbf{1 7 . 5}$ metric tons of wet biomass per hectare per day (approximately 0.88 metric tons dry matter per hectare per day, based on an estimated $5 \%$ solids per wet weight) when water hyacinths are grown in domestic sewage lagoons during the warm summer months.

In order to maximize the efficiency of nutrient removal by water hyacinths, the plants should be periodically harvested as they become saturated with excess nutrients. Ideally, the harvested plant material should be utilized, in order to defrity the costs of removal. Various investigators have proposed using harvested water hyacinths as foo! supplement both for caltle (Baldwin et al., 1974) and humans (Wolverton et al., 1976), as a soil additive (Gratch, 1965; Parra \& Hortenstein, 1974; Wolverton \& McDonald, 1976a), as a source of paper and fiber (Batgnall et al., 1974), and as an energy source (Wolverton \& McDonald, 1976b; Wolverton et al., 1975). The use of water hyacinths as a food source appears most promising. Gosset and Norris (1971) have demonstrated a definite relationship between nutrient availability and the nitrogen and phosphorus content of water hyacinths. Haller and Sutton (1973) analyzed water hyacinths grown in nutrient solutions with different phosphorus concentrations and found that the phosphorus content of the plants increased as the phosphorus content of the

\footnotetext{
- National Acronatulics and Space Administation, National Space 'Technology Laboratories, NS'TL Stalion. Mississippi 39524.

Submitted for publication October 26, 1977; accepted for publication December 1, 1977

ACCESSIONING, RETRULUCTION AND DISTRLBUITION

Ecomomic Boluny, 32(4), 1978, pp. 363-370

BK,OR EOR NASA PERMMIRIED
}

(9) 1974, by the New York Botanical Ciarden, Bronx, NY 10458 
I'ABLE: I

\begin{tabular}{|c|c|c|c|c|c|c|}
\hline \multicolumn{7}{|l|}{ NUTRIINILU } \\
\hline \multirow{3}{*}{$\cdots \cdots+\cdots$} & \multicolumn{4}{|c|}{ CONCTNIRATIONST } & $\cdots:: \cdots$ & $-\cdots$ \\
\hline & \multicolumn{2}{|c|}{$\begin{array}{c}\text { 5-I Dy biochemical } \\
\text { oxygen demand }\end{array}$} & \multicolumn{2}{|c|}{ Total Kjeldahl nitrogen } & \multicolumn{2}{|c|}{ Total phosphorus } \\
\hline & $k g / h a v d a y$ & Ib/ac/day & kghavday & Ib/ac/day & kg/havday & In/ac/day \\
\hline I.ucédale & 57 & 52 & 9.8 & 9.0 & 2.4 & 2.2 \\
\hline Orange Grove & 83 & 76 & 14.9 & 13.6 & 8.3 & 7.6 \\
\hline NSTL Lagoon \# I & 24 & 22 & 2.5 & 2.3 & 0.7 & 0.7 \\
\hline NSTL lagoon \#2 & 4 & 4 & 1.1 & 1.0 & 0.3 & 0.3 \\
\hline
\end{tabular}

water increased up to a maximum level of $40 \mathrm{ppm}$ phosphorus in the water. Because the nutrient composition of water hyacinths is generally proportional to the nutrient content of the medium in which the plants are grown, sewage-grown water hyacinths should be particularly high in protein and minerals.

Since 1975, NASA (Wolverton \& McDonald, 1976c) has been experimenting with the use of water hyacinths as a biological treatment method for domestic wastewaters. In this paper, we present the result of nutrient analyses of water hyacinths grown '). fut:! experimental sewage lagoons in southern Mississippi. Most workers investigating nutrient contents of the water hyacinth have analyzed whole plant tissue. We have examined the relative nutrient contributions of the roots, stems, and leaves. Analyses for vitamins and minerals were also performed.

\section{MAILRIALS AND MEIHODS}

The four sewage lagoons into which we have introduced water hyacinths are located in southern Mississippi. Two are located on NASA's National Space Technology Laboratories (NSTL), Bay St. Louis, and the other two serve small communities in the area. Nutrient loading rates are presented in Table $I$.

Plants were collected in late summer on the same date from four domestic sewage lagoons that had supported the growth of water hyacinths since spring. The plants were thoroughly washed with tap water. The leaves, stems and roots were separated from half the plants; the remainder of the plants were left intact. All samples were dried in an oven at $100^{\circ} \mathrm{C}$ for 24 hours and ground to an even consistency in a blender. The plant powder was analyzed for vitamins, minerals, amino acids, ash, fiber, and fat.

Analyses for vitamins, sulfur, total Kjeldahl nitrogen, total phosphorus, crude fiber, ether extract (fat), pepsin digestbility, and xanthophyll were done by Research 900 , St. Louis, Missouri.

The crude protein was calculated as Kjeldahl nitrogen $\times 6.25$.

The mineral analyses were determined by atomic absorption/flame emission with an IL 253 spectrophotometer following digestion of $0.50 \mathrm{~g}$ of plant material in $10 \mathrm{ml}$ concentrated nitric acid and $2 \mathrm{ml} 30 \%$ hydrogen peroxide. A blank was also analyzed for background correction.

Five-day biochemical uxygen demand $\left(\mathrm{BOD}_{5}\right)$, total Kjeldahl nitrogen (TKN), and total phosphorus analyses of the influent wastewater were performed according to Standard Methods (Franson et al., 1971). To determine the average nutrient loading rates, two grab samples per week were collected from the lagoon influent. The samples were collected for a period of one year from NSTL Lagoons 1 and 2 and over a six-month period from the other two lagoons. 
IAH। II

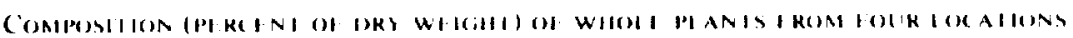

\begin{tabular}{|c|c|c|c|c|c|c|}
\hline l.ocation & $\begin{array}{l}\text { Cruele } \\
\text { probein }\end{array}$ & rill & liber & Ash & $\begin{array}{l}\text { kieldiahl } \\
\text { nilrogen }\end{array}$ & Phosphorus \\
\hline l.ucedale & 22.3 & $2 .(1) 4$ & 19.5 & 1.5 .1 & 3.56 & 0.89 \\
\hline ()rallge Grove & 23.4 & 2.20 & 17.1 & 20.4 & 3.74 & 0.8 .5 \\
\hline NSII Lagoon \#I & 17.1 & 1.59 & 18.6 & 11.1 & 2.73 & 0.45 \\
\hline NSIL I Iagoon \#? & 4.7 & 1.68 & 19.2 & 19.9 & 1.56 & 0.31 \\
\hline
\end{tabular}

RISUI IS AND DISCUSSION

\section{Gross composition}

As shown in Fable II, whole plants from different sampling locations were found to contain fairly constant amounts of fat, fiber and ash; findings for these constituents were quite comparable with those reported by other investigators (Boyd, 1970; Parra \& Hortenstein, 1974). Phosphorus content and crude protein, on the other hand, were found to vary considerably among the sampling sites. This is agatin consistent with the findings of other authors. Boyd (1970) noted that the protein content of water hyacinths declined with piant age and varied greatly among plants taken from different locations, in general reflecting the nutrient content of the waters in which they are grown. Gosset and Norris (1971) also found that both the nitrogen and the phosphorus content of water hyacinths increased with increasing concentrations of these nutrients in the culture solution. Our results corroborate these findings. Inspection of Tables I and II reveals a direct correlation between nutrient loading rate and crude protein content of the water hyacinths; titat is, plants grown in lagoons with higher loading rattes contain proportionally greater amounts of crude protein. At the highest nutrient loading rattes, the difference in percent crude protein is less pronounced (compare, for

TABII: III

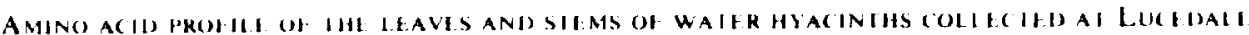
(G/100) (,) DHY WI:IGHI

\begin{tabular}{|c|c|c|}
\hline Amino acid & Leaves & Stems \\
\hline Aspartic & 3.77 & 5.71 \\
\hline Glutamic & 3.45 & 1.93 \\
\hline Alanine & 1.94 & 0.67 \\
\hline Isoleucine & 1.46 & 0.54 \\
\hline Phenylalanine & 1.70 & 0.59 \\
\hline Ammonia & 0.70 & 0.94 \\
\hline Threonine & $1.3 n$ & 0.54 \\
\hline Proline & $1.8 x$ & 0.62 \\
\hline Valine & 1.74 & $0.5 \mathrm{~K}$ \\
\hline 1.cucine & 2.59 & 0.85 \\
\hline Hislidine & 0.69 & 0.23 \\
\hline Arginine & 1.64 & 0.50 \\
\hline Serine & 1.28 & 0.50 \\
\hline Glycine & 1.61 & 0.59 \\
\hline Methionine & 0.44 & 0.14 \\
\hline Tyrosine & 1.06 & 0.37 \\
\hline Lysine & 1.78 & 0.54 \\
\hline Cysteine & 0.4119 & 0.122 \\
\hline Trupluphan & 0.309 & 0.167 \\
\hline
\end{tabular}


TäL.E. IV

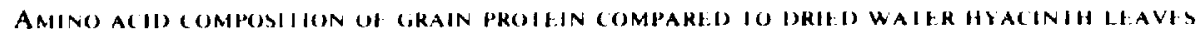

\begin{tabular}{|c|c|c|c|c|c|c|c|}
\hline & \multirow{2}{*}{$\begin{array}{l}\text { faij } \\
\text { relusence } \\
\text { palternd }\end{array}$} & \multicolumn{5}{|c|}{ Grams/100 g protein } & \multirow{2}{*}{$\begin{array}{c}\text { Watcer } \\
\text { hyaciulh } \\
\text { leaves grown } \\
\text { in human } \\
\text { waste }\end{array}$} \\
\hline & & Corn & Rice & Oats & Wheat & ghum & \\
\hline l.y vine & 4.2 & $0 . K$ & 3.5 & 4.0 & 2.6 & 1.8 & 5.7 \\
\hline Melhomine + Cysleine & 22 & 3.6 & 3.4 & $4 . x$ & 3.0 & 3.0 & 2.7 \\
\hline Threomine & 2.8 & 4. 1 & 3.3 & 3.6 & 3.0 & 3.6 & 4.3 \\
\hline Isoleucine & 4.2 & 6.4 & 4.5 & 4.0 & 3.4 & 4.5 & 4.7 \\
\hline Lelluine & 4.8 & 15.0 & 8.0 & 7.1 & 6.8 & 11.6 & 8.3 \\
\hline Valine & 4.2 & 5.3 & 5.4 & 5.1 & 4.6 & 5.4 & 5.6 \\
\hline Phenylablanine + Tryosine & 5.6 & 13.1 & 10.3 & 8.4 & 7.6 & 5.2 & 8.8 \\
\hline Tryplophan & 1.4 & & 0.6 & 0.9 & 1.1 & 0.8 & 1.11 \\
\hline Histidine & & & 2.2 & 2.2 & 2.3 & 2.0 & 2.2 \\
\hline Arginine & & & 7.8 & 6.J & 4.7 & 3.4 & 5.2 \\
\hline
\end{tabular}

"Burton, B. I. 1976. Huntan Nutrition. McGiaw-Hill Book Co., New York, p. 162.

example, Lucedale with Orange Grove, Tables I \& II); indicating that plant protein is reaching a maximum level.

One reason that water hyacinths are so effective at removing excess nutrients is that they exhibit luxury consumption, particularly of phosphorus. That is, they will absorb more of this nutrient than they can utilize for growth. (Excess phosphorus is stored within the plant (issue.) In a study concerning the effects of high phosphorus concentration on growth of the water hyacinth, Haller and Sutton (1973) found that this plant can absorb roughly four times more phosphorus than

JАВ I. V

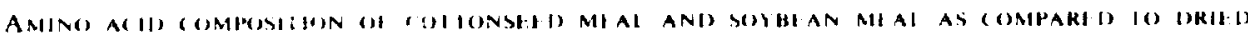

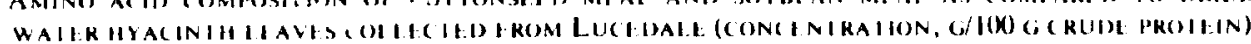
WAITK HYACINIH IIAVIS

\begin{tabular}{|c|c|c|c|}
\hline Amino acid & Cotlonseed meal" & Soybean meal" & hyacinth leaves \\
\hline 1.y sine" & 5.40 & 6.49 & 5.68 \\
\hline Histidine & 2.16 & 2.63 & 2.20 \\
\hline Arginine & 5.17 & 6.98 & 5.23 \\
\hline Aspartic & 19.22 & 12.18 & 12.03 \\
\hline Threonine" & 4.86 & 4.26 & 4.34 \\
\hline Serine & 4.94 & 5.51 & 4.08 \\
\hline Glutamic & 13.66 & 19.36 & 11.01 \\
\hline Proline & 5.02 & 5.29 & 0.000 \\
\hline (ilycine & 5.56 & 4.48 & 5.14 \\
\hline Alanine & 6.33 & 4.58 & 6.19 \\
\hline Valime" & 5.48 & 4.80 & 5.55 \\
\hline Methonime" & 1.31 & 1.37 & 1.40 \\
\hline Isoleucine" & 4.40 & 4.90 & 4.66 \\
\hline Leucine" & 7.80 & 7.98 & 8. 26 \\
\hline Tyrosine & 3.55 & 3.94 & 3.38 \\
\hline phenylalanine" & 5.10 & 5.37 & 5.42 \\
\hline 'Tryplophatl" & & & 0.94 \\
\hline Crude protein $(\%)$ & 39.1 & 44.5 & 31.3 \\
\hline
\end{tabular}

“ Coltonseed meal and soybean meal analysis supplied by Mississippi Siate University.

b Essential amino acids. 


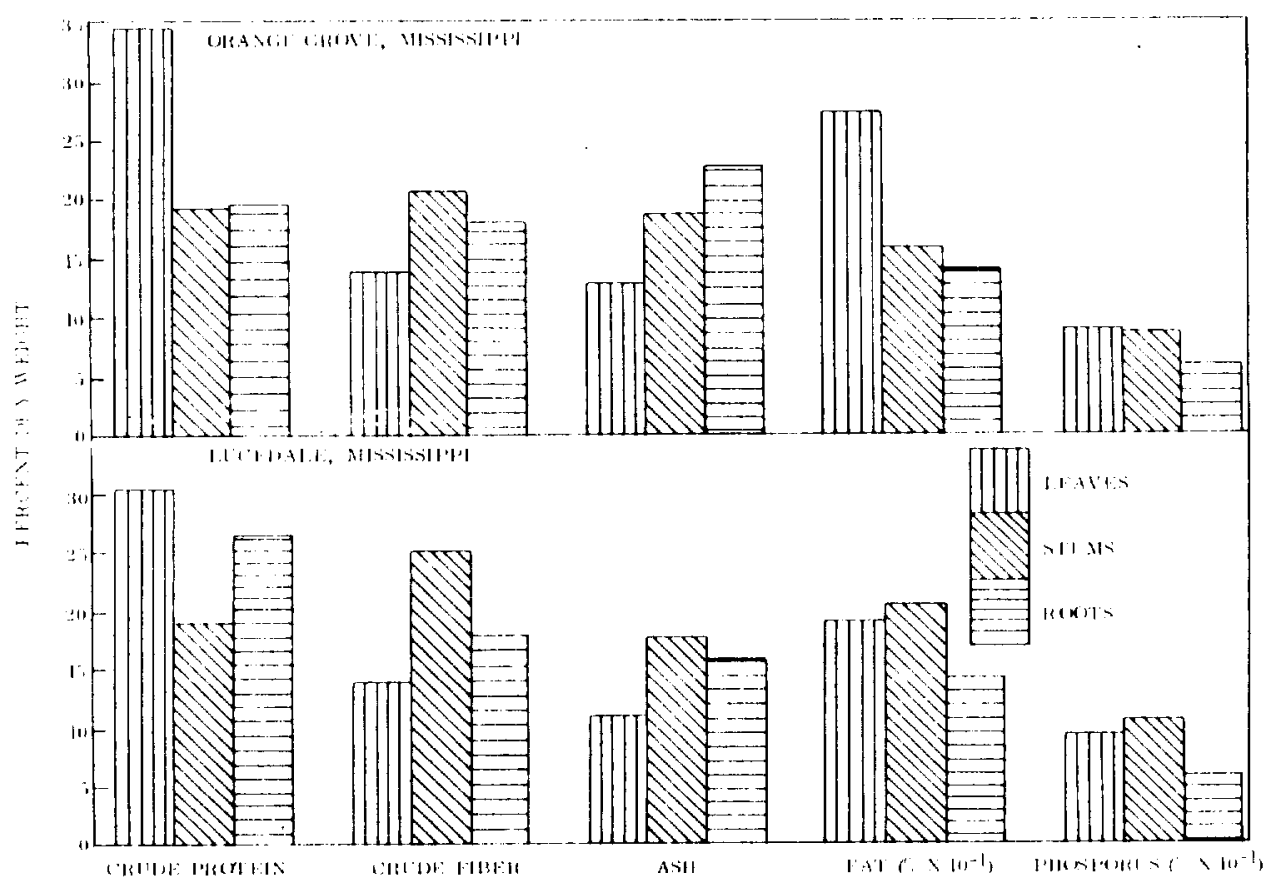

Ifu. 1. Partitioning of nutrients in sewage-grown water hyacinths from two locations.

other plants which have been previously studied. These authors found that, at moderate phosphorus concentrations $(5-10 \mathrm{mg} / \mathrm{l})$, phosphorus within the plants was concentrated mostly in the leaves and stems, while at concentrations exceeding $20 \mathrm{mg} / \mathrm{l}$, phosphorus was distributed more uniformly throughout the plant tissue. We also found roughly $66 \%$ more phosphorus in the leaves and stems than in the routs of the plants we sampled (Fig. 1); phosphorus concentration of the influent water ranged from $8.47-9.70 \mathrm{mg} / 1$.

Other plant constituents also showed some partitioning within the plant tissue (Fig. 1). For example, leaves were found to contain the highest percentage of crude protein and the lowest percentage ash. The stems contained the largest portion of the plaini fiber. Thus, the leaves of the water hyacinth would produce the greatest percent yield for protein extraction. However, this is somewhat misleading; because the stems comprise a much greater percentage of the total plant mass, they also contain a considerable amount of protein.

TABLE VI

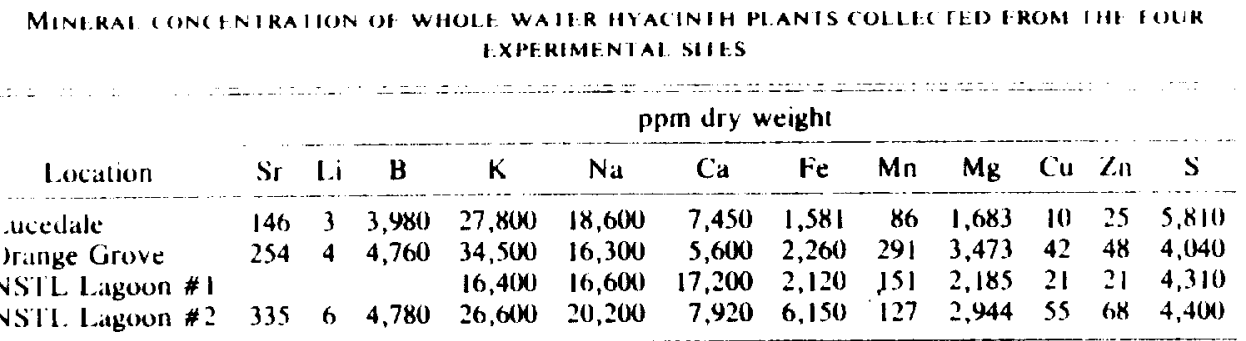


IABLE: VII

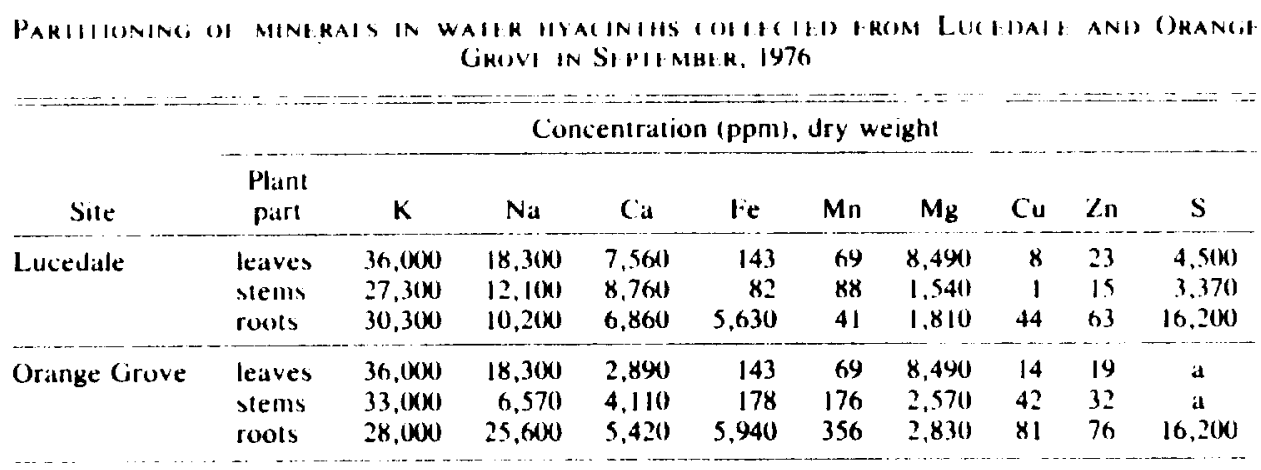

"Insufticient sample available for analysis.

\section{Amino acid composition}

The amino acid composition of water hyacinth leaves and stems collected in September from Lucedale is presented in Table III. The relative amounts of certain amino acids differ considerably from those previously reported (Boyd, 1970: Taylor et al., 1971; Taylor \& Robbins, 1968); apparently, the ratio of the plant's constituent amino acids is strongly affected by environmental variables and perhaps seasonal variables as well.

Comparison of the amino acid composition of water hyacinth leaves with that of grain crop species and the FAO reference pattern (Table IV) reveals that the water hyacinth would make an excellent protein source and could be used as a dietary supplement to balance the amino acid intake in a predominantly grain diet. For example, water hyacinth could be used to supplement the lysine content of a corn diet for cattle or a rice diet for humans. A diet consisting mainly of wheat could be enriched in lysine, threonine, isoleucine, leucine, phenylalanine, tyrosine, valine, and arginine by the addition of water hyacinth protein. As shown in Table $V$, water hyacinth leaves compare favorably with the crude protein and amino acid content of high protein crops such as cottonseed and soybean.

\section{Minerals and irtamins}

The mineral composition of water hyacinths is presented in Tables VI and VII. As shown in Table VII, most minerals are present throughout the plant tissue.

TABLE VIII

MISCHII ANEOUS VIIAMINS AND NUIRIEN I VALUES TOR WATER HYACINTH LEAVES FROM LUCEDALE SH.WAGE LAGOON

\begin{tabular}{lc} 
Vilatsins and nutrients & Concentration, dry weight \\
Thiamine $\mathrm{HCl}\left(\mathrm{B}_{1}\right)$ & $5.91 \mathrm{ppm}$ \\
Riboflavin $\left(\mathrm{B}_{2}\right)$ & $30.7 \mathrm{ppm}$ \\
Vitamin $\mathrm{E}$ & $206 \mathrm{ppm}$ \\
Pyroxidine $\mathrm{HCl}\left(\right.$ Vitamin $\left._{\mathrm{s}}\right)$ & $15.2 \mathrm{ppm}$ \\
Vitamin A & $2.45 \mathrm{ppm}$ \\
Chemical niacin & $79.4 \mathrm{ppm}$ \\
Pantothenic acid & $55.6 \mathrm{ppm}$ \\
Pepsin Jigestibility & $67.0 \%$ \\
Xanthophyll & $485 \mathrm{ppm}$ \\
Vitamin $\mathrm{B}_{1:}$ & $0.0126 \mathrm{ppm}$ \\
& (roots: $0.682 \mathrm{ppm})$ \\
\hline
\end{tabular}


IAHI: IX

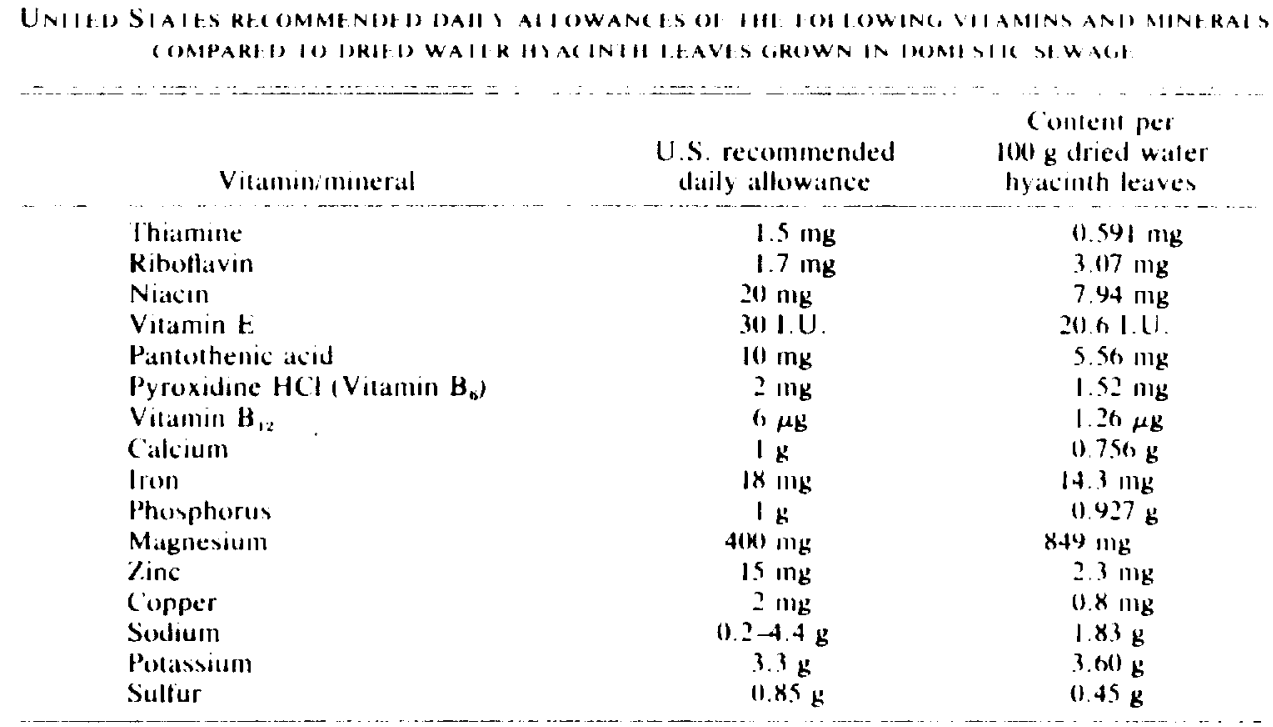

However, iron and, perhaps, copper and sulfur are concentrated in the roots, while magnesium appears to be concentrated in the leat tissue. No toxic levels of lead, silver, cadmium or chromium were detected in the plant lissue. When detected at all, the amounts of these substances were no greater than those present in soybean and cottonseed meal.

The relatively high mineral content of the water hyacinth, comparable to that of many crop species, suggests that this plant could make a good soil additive as well as a dietary supplement. In a study comparing water hyacinth with commercial fertilizer, Parra and Hortenstein (1974) found that water hyacinth applications produced as good or better crop yields than did applications of commercial fertilizers for certain soil types. Basak (1948) found that the nutrient content of water hyacinth compost was approximately four times greater than that of farmyard manure and twice as great as compost prepared from town refuse and night soil. The mineral values of our sewage-grown hyacinths are similar to those reported by Parra and Hortenstein, except the Mississippi hyacinths contain slightly more sodium and considerably more calcium and copper than they reported.

The vitamin contents of sewage-grown water hyacinth leaves are presented in Table VIII. Vitamins may be even more concentrated in other plant parts. For example, the roots contain over 50 times the amount of vitamin $B_{12}$ that is present in the leaves. A comparison of the content of selected vitamins and minerals in water hyacinths with that of the United States recommended daily allowance is shown in Table IX.

\section{CONCLUSIONS}

Inspection of Tables IV, V, and IX reveals that the water hyacinth could be an excellent source of proteins, vitamins, and minerals, and could be of particular value as a dietary supplement in countries where human diets are generally deficient in these nutrients. The high water content of $E$. crassipes $(95 \%)$ makes utilization of this species difficult on a large-scale commercial basis. However, we feel that this fast-growing plant species would be beneficial to human diets on 
an individual basis, because less than $3 \mathrm{~kg}$ of harvested, fresh water hyacinth leaves could provide essentially all of the protein, minerals and vitamins required daily in the human diet. We are currently experimenting with low-cost harvesting and processing methods which should make the utilization of water hyacinth nutrients more feasible on a large-scale basis.

\section{IIITRAIURF (IIED}

Bagnall, L. O., T. S. Furman, J. F. Hentges, W. J. Noland \& R. W. Shirley. 1974. Feed and tiber from eftluent-grown water hyacinth. $I n$ : Wastewaler Use in the Production of food and Fiber. Proceedings. Environmental Protection Agency Technology Series F.PA 660/2-74-(14) I. NTIS, Springfield, VA.

Baldwin, J. A., J. F. Hentges \& L. O. Bagnall. 1974. Preservation and cattle atcceptability of water hyacinth silage. Hyacinth Control J. 12: 79.

Basak, M. N. 1948. Water hyacinth compost. Pp. 13-15. In: Little, E. C. S., ed. 1968. Handbouk of Utilization of Aquatic Plants. FAO publication

Bates, R. P. \& J. F. Hentges. 1976. Aquatic weeds-eradicate or cultivate? Econ. Bot. 30: 39-50.

Boyd, C. E. 1970. Vascular aquatic plants for mineral nutrient removal from polluted waters. Econ. Hot. 24: 95-103.

(cornwell, D. A., J. Zoltck, Jr., C. D. Patrinely, T. deS. Furman \& J. I. Kim. 1977. Nutrient removal by water hyacinths. Journal Witter Pollution Control Federation 70: $57-6.5$.

Franson, M. A., M. C. Rand, A. E. Greenberg \& M. J. Taras, eds. 1971. Standard Methods for the Examination of Water and Wastewater, 13th Edition. APHA-AWWA-WPCF publication. John D. Lucas Co., Baltimore, Md.

Gosset, D. R. \& W. E. Norris, Jr. 1971. Relationship between nutrient availability and content of nitrogen and phosphonus in tissues of the aquatic macrophyte Eichhormia irasipess (Mart.) Solms. Hydrubiol. 38: 15-28.

Gratch, $H$. 1965. Water hyateinth-a menace that could be lumed to a blessing. P. I6. In: Litle, $F$. C. S., ed. 1968. Handbook of Utilization of Aquatic Plants. FAO publication

Haller, W. T.\& D. L. Sutton. 1973. Effect of $\mathrm{pH}$ and high phosphorus concentraltoms on growth of water hyacinths. Hyacinth Control J. 11: $59-63$.

Holm, L. G., L. W. Weldon \& R. D. Blackburn. 1969. Aquatic weeds. Science 166: 699.

Miner. J. K., J. W. Wooten \& J. D. Dodd. 1971. Water hyacinths to further treat anaterobic ligoon effluent. Pp. 170-173. In: Livestock Waste Management and Pollution Abatement. American Sociely of Agricultural Engineers, St. Joseph, Michigan.

Parra, J. V. \& C. C. Hortenstein. 1974. Plant nutritional content of some Florida water hyacinths and response by pearl millet to incorporation of water hyacinths in three soil types. Hyacinth ('ontrol J. 12: K5-9)

Raynes, J. J. 1972. History of aquatic weed problems in the Southeastern United States. Proc. So. Weed Sci. Soc, 25: 360-364.

Rogers, H. H. \& D. E. Davis. 1972. Nutrient removal by water hyacinths. Weed Science 20: 123128.

Sheffield, W. C. 1967. Water hyacinth for nutrient removal. Hyacinth Control J. 6: 27-30.

Faylor, K. G., R. P. Bales \& R. C. Robbins. 1971. Extraction of protein from water hyacinth. Hyacinth Control J. 9: 20-22.

Taylor, K. G.\& R. C. Robbins. 1968. The anino acid composition of water hyacinth teichtormia (rassipes) and its value as a protein supplement. Hyacinth Control J. 7: 24-25.

Westlake, D. F. 1963. Comparisons of plant productivity. Biol. Rev. 38: 384-425.

Wolverton, B. C., R. M. Barlow \& R. C. McDonald. 1976. Application of vascular aquatic plants for pollution removal, energy, and food production in a biological system. Biological Control of Water Pollution. University of Pennsylvania Press, Philadelphia, PA, pp. 141-149.

\& K. C. M. Dunald. 1976a. Don't waste water weeds. Neiw Scientist, 12 Aug 1976: 318-320

\& 1976b. Watter hyacinths, Eichhornia crassipes (Mart.) Solms, a renewable source of energy. Proceedings of a conference on capturing the sun through bioconversion, coordinated by Washington Ceniter for Metropolitan Studies, Washington, D.C. Pp. 249-252.

- \& 197k: Water hyacinth for upgrading sewage lagouns to meet advanced wastewater treatment standards: Part II. NASA Technical Memorandum TM-X-72730.

. _ \&. Gordon. 1975. Bio-conversion of waler hyacinths into methane gas: Part 1 NASA Technical Memorandum TM-X-72725. 